\title{
Endogenous Growth Theory and Regional Extensions
}

Citation for published version (APA):

Acs, Z., \& Sanders, M. (2021). Endogenous Growth Theory and Regional Extensions. In M. M. Fischer, \& P. Nijkamp (Eds.), Handbook of Regional Science (pp. 615-634). Springer, Berlin, Heidelberg. https://doi.org/10.1007/978-3-662-60723-7_13

Document status and date:

Published: 01/01/2021

DOI:

10.1007/978-3-662-60723-7_13

Document Version:

Publisher's PDF, also known as Version of record

Document license:

Taverne

Please check the document version of this publication:

- A submitted manuscript is the version of the article upon submission and before peer-review. There can be important differences between the submitted version and the official published version of record.

People interested in the research are advised to contact the author for the final version of the publication, or visit the DOI to the publisher's website.

- The final author version and the galley proof are versions of the publication after peer review.

- The final published version features the final layout of the paper including the volume, issue and page numbers.

Link to publication

\footnotetext{
General rights rights.

- You may freely distribute the URL identifying the publication in the public portal. please follow below link for the End User Agreement:

www.umlib.nl/taverne-license

Take down policy

If you believe that this document breaches copyright please contact us at:

repository@maastrichtuniversity.nl

providing details and we will investigate your claim.
}

Copyright and moral rights for the publications made accessible in the public portal are retained by the authors and/or other copyright owners and it is a condition of accessing publications that users recognise and abide by the legal requirements associated with these

- Users may download and print one copy of any publication from the public portal for the purpose of private study or research.

- You may not further distribute the material or use it for any profit-making activity or commercial gain

If the publication is distributed under the terms of Article $25 \mathrm{fa}$ of the Dutch Copyright Act, indicated by the "Taverne" license above, 


\title{
Endogenous Growth Theory and Regional Extensions
}

\author{
Zoltan Acs and Mark Sanders
}

\section{Contents}

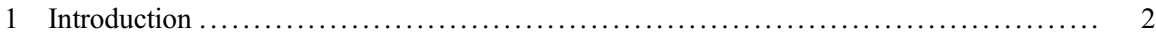

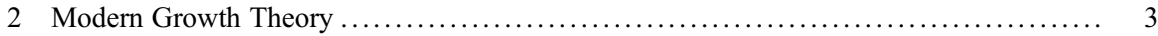

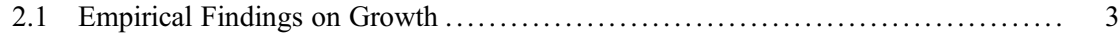

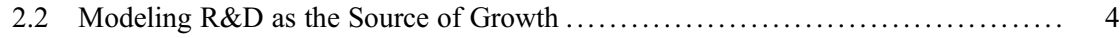

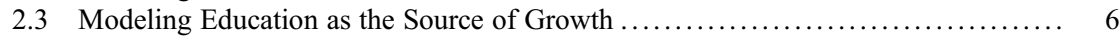

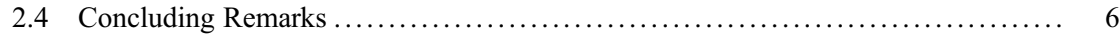

3 The Geography of Knowledge Creation and Diffusion ........................... 7

3.1 Clusters and Agglomeration .......................................... 7

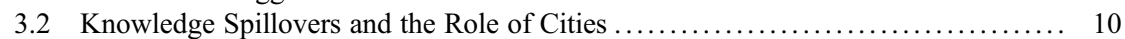

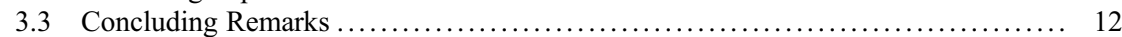

4 The Organization of Knowledge Creation and Diffusion ........................... 12

4.1 Organizational Change as the Enabler of Economic Growth .................. 12

4.2 Entrepreneurship as the Conduit for Knowledge Spillovers .................... 13

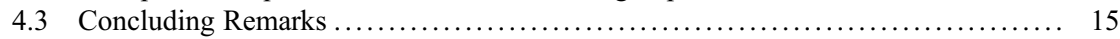

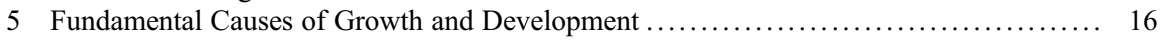

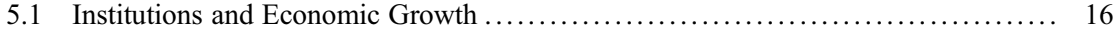

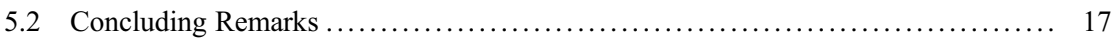

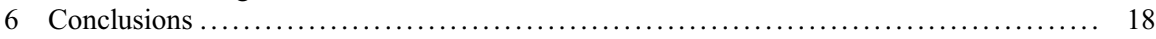

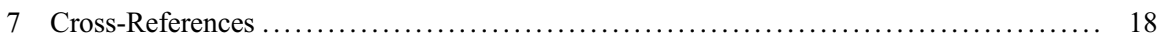

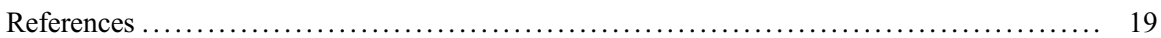

Z. Acs

Schar School of Policy and Government, George Mason University, Fairfax, VA, USA

e-mail: zacs@gmu.edu

M. Sanders (ه)

Utrecht School of Economics, Utrecht University, Utrecht, The Netherlands

e-mail: m.w.j.1.sanders@uu.nl 


\section{Abstract}

In this chapter, we outline the basic mechanisms in endogenous growth theory that identify knowledge creation and diffusion as the core driver of economic growth. Then we discuss how new economic geography, urban economics, organizational science, and entrepreneurship theory have "regionalized" the mechanisms involved. Knowledge creation, however, has been dubbed a "proximate cause" of growth, and the quest for "fundamental causes" has continued. We discuss this recent development in macroeconomic growth theory and argue that the new "institutional approach to growth" opens up a lot of new avenues for future research. Once again, the importance of cities, organizations, and entrepreneurship is largely ignored in macro growth theory. Yet economic geography, urban economics, organizational science, and entrepreneurship theory have a lot to contribute to growth theory by both empirically and theoretically developing our understanding of local institutions and linking these to regional economic development and growth.

\section{Keywords}

Growth · Entrepreneurship · Economic geography · Region · Urban economics · Organizational science

\section{Introduction}

Growth at the regional level can be understood as the increase in economic activity in that region over a period of time. We can measure this empirically (with all wellknown caveats) by the annual increase in GDP or employment at the regional level. The sources of economic growth have always been the subject of intense academic investigation. However, the resulting state-of-the-art modern economic growth theories, as, for example, presented in Barro and Sala-I-Martin (2004) and Acemoglu (2009), largely abstract from geography. That is, the process of economic growth is investigated without considering the location and regional setting in which it is taking place. Of course that will not do for the purposes of this Handbook.

The literature shows that there is large variation in regional levels and growth of GDP. Barro and Sala-i-Martin (2004) present tests of convergence among regions, showing slow convergence exists but migration and capital mobility fail to eliminate regional variation in development levels, even over long periods of time and among well-integrated regions. We have seen many possible explanations being offered and empirically investigated in other chapters of this part of the Handbook. All in one way or another suggest that although cross regional spillovers are significant, the growth and development process is also very much a localized process. In this chapter, we will discuss at some length the models and theories that explicitly link economic activity and development to regional circumstances.

But before we discuss such extensions to the basic framework, it is useful to review modern growth theory. Then we can discuss the various ways in which these 
models have been "regionalized" in the literature on new economic geography, urban economics, and the spillover theory of entrepreneurship. These literatures all build on the first generation of ideas in innovation-driven endogenous growth theory. We can then review the implications of the more recent institutional approach to economic growth. Barro (1996) and Acemoglu et al. (2001) pioneered this approach, but here too geography is largely ignored. A natural way to link institutions and growth at the regional level is to consider the link Baumol (1990) proposed between productive entrepreneurship and institutions. That is, the institutions in place determine whether entrepreneurial talent allocates into productive, unproductive, or even destructive activities (Desai et al. 2013; Sanders and Weitzel 2013). The institutional approach to growth has opened up new and exciting research avenues for building regional endogenous growth models. Progress has been made in recent contributions to the literature, but important questions remain.

\section{$2 \quad$ Modern Growth Theory}

\subsection{Empirical Findings on Growth}

Solow (1957) already found that over $90 \%$ of the variation across US states in GDP per capita growth was due to productivity increases. His work sparked a large literature on the rate of technological change, where the empirical literature sought to adequately measure productivity and look for statistically significant correlations with possible explanatory variables. The (mainstream) theoretical literature, meanwhile, built on the evidence and formulated new hypotheses and models that try to endogenously explain the rate of technological change and productivity growth as the result of (rational) behavior of economic agents.

As technical change is an illusive concept that is hard to measure or observe directly, the empirical evidence in support of the claim that innovation is important is convincing yet circumstantial. Long-run economic growth and the income distribution have been attributed to technical change and innovation by elimination of all other possible sources. The empirical literature on economic growth has been surveyed in much more detail than we can hope to achieve in this chapter by, e.g., Temple (1999) and Barro and Sala-i-Martin (2004). From their surveys we learn that growth rates tend to remain positive in the long run and differ a lot for long time spans among countries. Temple (1999) surveys the evidence that links these crosscountry differences to the proximate causes of growth: investment in physical capital (machinery, equipment, and infrastructure), investment in human capital, and investment in research and development.

In particular in explaining differences between developing and developed countries, the investment in physical capital seems a strong candidate. Differences among developed countries are attributed inter alia to knowledge creation (e.g., R\&D), although there is also strong evidence for international spillovers of knowledge. The evidence on human capital accumulation through education is mixed. The empirical literature on these issues, however, typically struggles with the statistical problem to 
separate cause and effect as investments in knowledge creation and education may both affect and be affected by economic development.

In addition to these proximate causes, Temple (1999) discusses evidence on the impact of population growth, trade openness, financial development, macroeconomic stability (low and stable inflation and unemployment rates), inequality, political and civil rights, the size of government, and public infrastructure investments. All these factors are, however, believed to work through, or as moderators of, the impact of knowledge creation.

In the empirical literature, one can find various exogenous and semi-endogenous representations of technological change. Through introducing time trends, accumulated production, new capital investment, imports and exports, etc. as arguments in growth regressions or regression equations for production frontiers or cost curves, this literature has explicitly or implicitly introduced and developed ways to represent learning by doing (cumulative production), learning by investing (capital accumulation), embodied technical change (new capital goods), imported technology (imports), and learning by exporting (exports). The latter representations, however, can still not be called "endogenous technological change" in the true sense of the word. The empirical models assume a relation between technology and other (endogenous) variables such as cumulative production, but do not explain the mechanism and behavior behind this relation. Going from empirical measures and representations of technology to actually explaining the phenomenon requires a theoretical model that illustrates how behavior of agents in response to incentives and constraints leads to innovation and technological change.

A fundamental proposition in new growth theory is that rational agents create and accumulate knowledge for profit. In accordance with the findings in the empirical literature discussed above, theory has explored R\&D and education (human capital) as the sources of growth. In addition, and more recently, organizational change and institutional development have been identified as key enablers or "fundamental causes" of economic growth.

\subsection{Modeling R\&D as the Source of Growth}

With Romer (1990), Aghion and Howitt (1991), and Grossman and Helpman (1991a), a strand of models has developed in which R\&D, the conscious and deliberate investment of resources in knowledge creation, generates inventions that generate productivity growth. The 2018 Nobel Prize in economics was awarded to Romer for his pioneering role in this literature, and his model serves well to explain the basic ingredients in an endogenous, knowledge-driven growth model. The structure of the Romer (1990) model is illustrated in Fig. 1.

The arrows (i)-(xiii) represent financial flows. Consumers spend on final goods (i) and save part of their income (ii) by purchasing assets. Their income consists of capital (iii) and labor income (iv). The final goods producers hire labor (v) and buy intermediate goods (vi) that are imperfect substitutes in production and supplied by monopolistic intermediate producers that only hire raw capital (vii) as their input. 


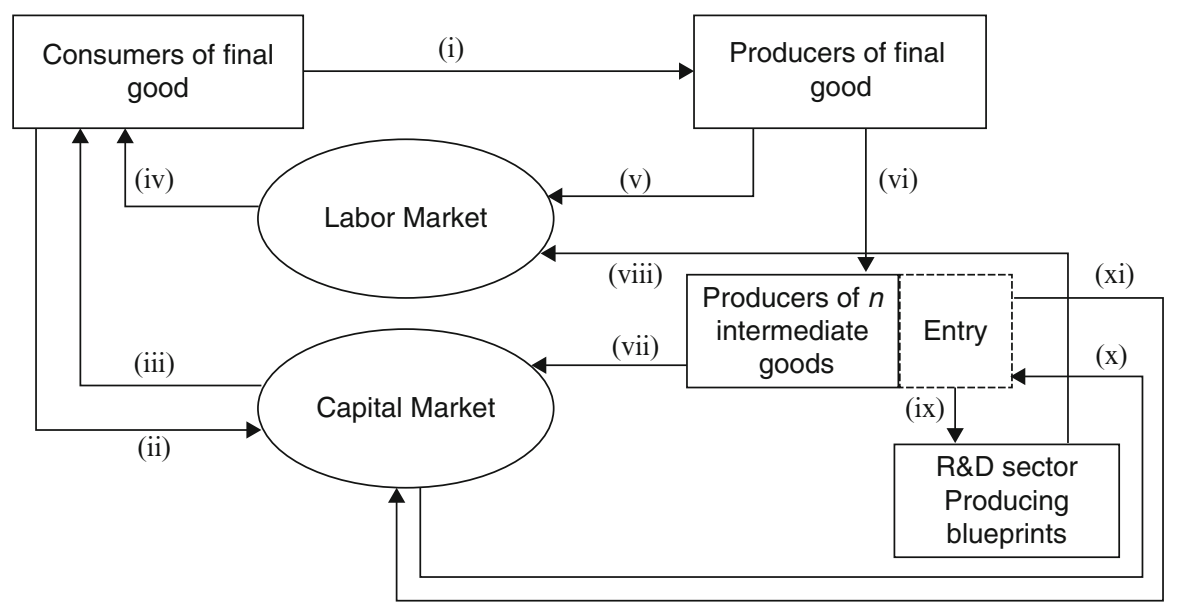

Fig 1 The Romer (1990) model

Given that there are monopoly profits in intermediate goods production and latent demand for new intermediates is positive, there is an incentive for the R\&D sector to hire labor (viii) and produce new blueprints that are sold (ix) to new entrants, who have to borrow (x) and repay (xi) this loan.

Similar diagrams for the Grossman and Helpman (1991a) (there are no intermediates but final goods are imperfect substitutes in consumption) and Aghion and Howitt (1991) (there is no variety expansion but quality improvement of existing intermediates) models would look slightly different, but as Grossman and Helpman (1991a) show, the qualitative results and key driving mechanisms remain the same. Based on these four basic models, a large literature has emerged in the 1990s, presenting models that focus on the accumulation of tradable knowledge embodied and codified in patents, products, and processes.

The basic behavioral assumption in these models is perfect rationality. Representative agents maximize utility or profits and are constrained by market (demand functions) and technological (production functions) circumstances. These behavioral assumptions are very strong and lack a strong empirical basis. The models should therefore not be taken too literally. Rather, in explaining the mechanism through which an economy with purely rational agents would generate innovation, the models show why it pays to innovate. Such mechanisms then also produce a tendency toward productivity growth when more realistic behavioral heuristics such as learning and evolutionary dynamics are applied. Such extensions and adaptations, however, usually come at the cost of more complexity and loss of tractability. As consumption, (intermediate) production, and R\&D are typically geographically concentrated and nonrandomly distributed in space, a clear link to regional models of growth can easily be built in.

The key insight to be taken away from these models is that investments in knowledge creation will generate innovation and economic growth when the private 
returns to knowledge creation, ultimately related to consumers' preferences, justify private investments in knowledge creation. The public good nature of knowledge (non-rivalry) then implies increasing returns to knowledge accumulation in the aggregate and allows for growth to be positive in equilibrium. Typically the knowledge generated in the past is assumed to be available and increase the productivity of knowledge generation in the present. This externality drives growth and is assumed to arise automatically. But it is not a big leap to link such spillovers to regional and local variables such as proximity and density. The private rewards to innovation, in addition, typically come from some sort of entry barrier that protects the innovator. This is another way in which (local, regional, or (inter)national) conditions may enter the debate.

\subsection{Modeling Education as the Source of Growth}

Following the original ideas of Becker (1964), Lucas (1988) pursued the idea that human capital accumulation through education generates productivity growth. Lucas (1988) presented a model (see Fig. 2) in which rational agents consume (i) and invest in their education (ii) in response to expected private future benefits.

Production uses raw labor (iii) and human capital (iv) so it benefits from higher human capital levels, but because the educational sector also uses human capital (v), education makes both production and the future education process more productive in his model. Lucas thereby introduces aggregate increasing returns to knowledge accumulation as in the models above. In this model, however, the knowledge accumulates in the working population, not in some disembodied knowledge base or in the technology embodied in the physical capital stock. It would therefore make sense to interpret that type of technological change as quality improvement of labor inputs.

The key to generating endogenous growth with human capital is again introducing externalities and spillovers that create increasing returns at the aggregate level. As Lucas (1988) himself immediately recognized, however, the productivity of human capital depends a lot on the presence of other educated workers in close proximity. He therefore discussed at some length the role of cities in economic growth and of human capital spillovers in holding cities together.

Of course the educational level of the population also plays a role in the R\&Ddriven growth models, as R\&D typically requires high-skilled (technical) personnel. The two models combined would therefore allow for education to affect productivity directly but also indirectly through the increased (productivity of) R\&D activities.

\subsection{Concluding Remarks}

Modern economic growth theory has focused on knowledge accumulation in the workforce and the aggregate production system as the long-run sources of economic growth. It models how rational decision-makers are privately induced to produce 


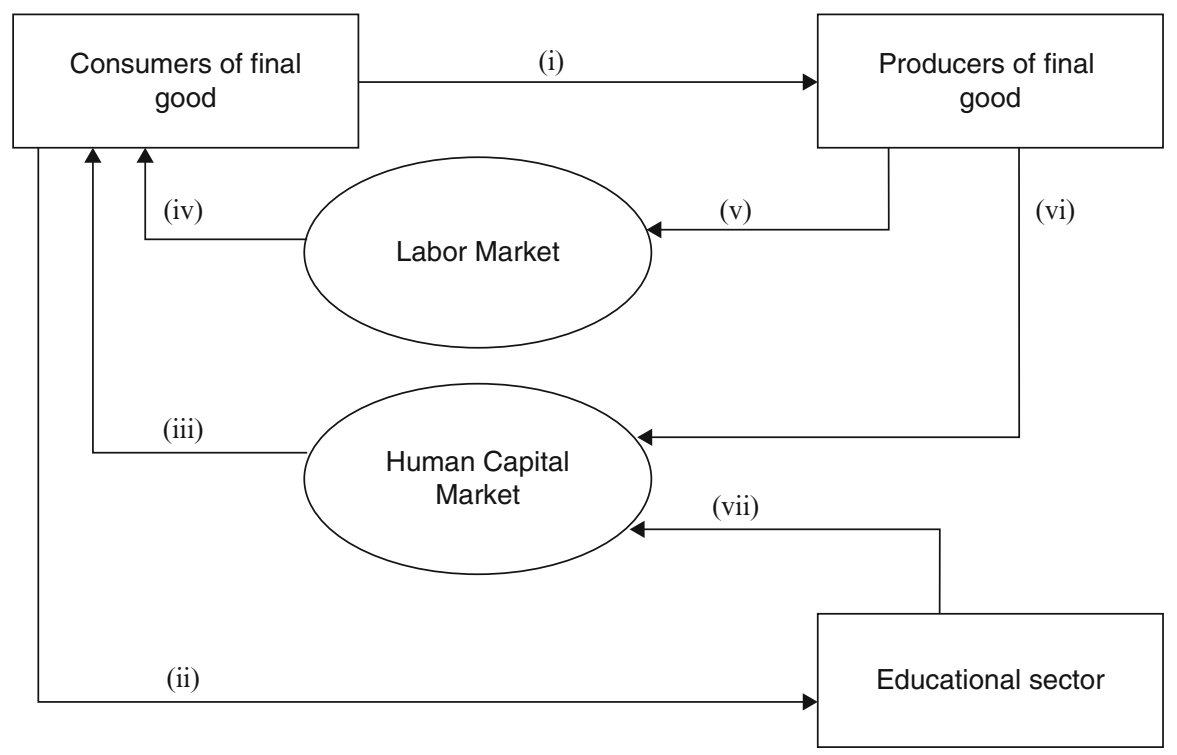

Fig 2 The Lucas (1988) model

knowledge and thereby create economic growth as a positive externality. Education makes all workers more productive, new technologies make further innovation easier, and new knowledge, once created, is non-rival in use. In these models economic growth comes from the increasing returns to human capital and knowledge creation that exist at the aggregate level.

The first generation of endogenous growth models predicted that economies with a larger workforce would experience higher growth (the so-called scale effect, e.g., Jones, 1995). This led many to propose alternative specifications that do not suffer from this apparent flaw. But once one realizes that the "aggregate level" of an economy is not the same as the size of a nation's workforce and the appropriate level of analysis is not the national but the regional or even local level, scale and density become similar concepts, and we can start to rethink the implications of endogenous growth in a slightly different direction.

\section{The Geography of Knowledge Creation and Diffusion}

\subsection{Clusters and Agglomeration}

It is a well-established empirical regularity in economic geography that population, and with it economic activity, is highly concentrated in urban centers. In addition, it follows a remarkably stable distributional pattern, known as Zipf's law. Zipf's law states that population centers, ranked by size, will decline in size proportionately to their rank. This implies that if the second city in a region has half the population of 
the first, the third has one third, etc. Moreover, Zipf's law has been shown to hold for the distribution of population in space at the national, regional, and even agglomeration level in, e.g., Germany by Giesen and Südekum (2011).

This pattern of spatial distribution interacts with another important empirical regularity in economic geography, known as the gravity equation. The gravity equation was proposed to explain the intensity of interactions between countries but can also be applied to interaction between and within clusters of economic activity at lower aggregation levels. The gravity equation explains, for example, trade and migration flows as a function of GDP of the origin and destination regions and the distance between two locations. In empirical work on Zipf's law and the gravity equation, the explanatory power of these relatively simple models is often above $90 \%$ of the variation to be explained across regions. This suggests that coreperiphery clusters are remarkably common and their general spatial structure and the linkages between constituent parts are similar.

Early work on the economics of agglomeration of industries identified the availability of inputs (specialized labor, other non-tradable specialized inputs) and access to output markets as key reasons for the spatial agglomeration of industries and argued that in agglomerations the informational spillovers would improve productivity. In his seminal contribution, Paul Krugman (1991) presented a model that generalized this intuition using among other things newly developed endogenous growth modeling tools. By now there are many excellent textbook treatments of his basic model.

Intuitively the model exploits a "circularity" or positive feedback loop. Consider an economy with agriculture and manufacturing. Agriculture is obviously located where the land is fertile. With high transportation costs and limited economies of scale in manufacturing, manufacturers will want to locate close to their demand. In a largely agricultural economy, this implies manufacturing is distributed in space pretty much in the same way as arable land. If on the other hand economies of scale are strong and transportation costs are low, manufacturing will begin to cluster. And if manufacturing workers also provide most of the demand for manufactured products, the process of agglomeration will feed on itself.

The model can be represented in a figure similar to the one provided for the Romer (1990) and Lucas (1988) models above. It is immediately clear from Fig. 3 that the ingredients of the Krugman (1991) model can easily be connected to the core elements in innovation-driven endogenous growth models. Krugman (1991) assumed two regions and imperfect substitutes and monopolistic competition in both manufacturing sectors. That is, consumers from both regions receive labor income (i) and consume local food (ii), but both purchase locally produced (iii) and imported (iv) manufactures. Both food production (v) and manufacturing (vi) use labor only in the basic model. Krugman (1991) then focused on labor migration and investigated how differences in wages (vii) might trigger movements of labor, explaining the emergence of core-periphery patterns.

The Krugman (1991) model predicts that in a perfectly symmetric situation, the wages for manufacturing workers are equal in both regions, and there will be no pressure for migration or clustering. If, however, the initial manufacturing workforce 


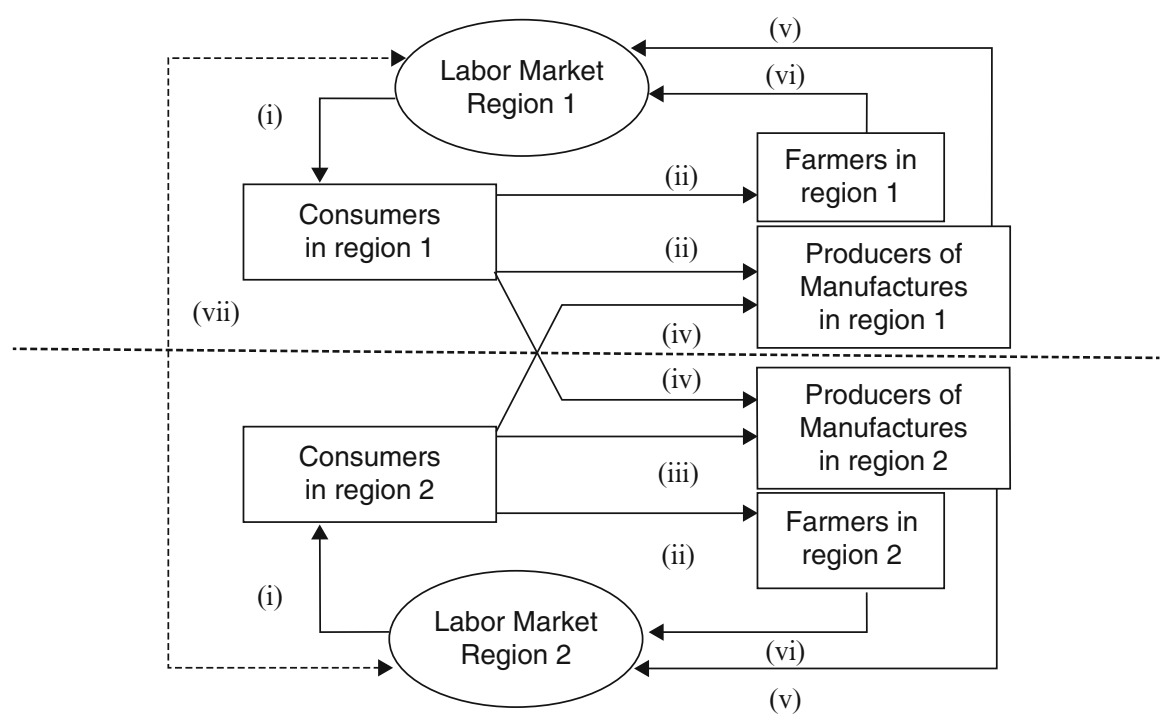

Fig 3 The Krugman (1991) model

is not symmetrically distributed, there are three competing effects on the relative (real) wage of manufacturing workers. On the one hand, the region with the larger market pays higher manufacturing wages because scale economies reduce costs and the larger market is cheaper to service in the presence of transportation costs. In addition, the lower price of manufactures due to competition increases the real value of wages in the larger market. On the other hand, there is less competition for the demand for manufactures from agricultural workers in the smaller market. The strength of these competing forces depends on the share of agriculture and manufacturing in total income, the degree of competition among manufacturers, and the level of transportation costs.

For regional endogenous growth, this model has important implications. The sources of aggregate increasing returns in modern manufacturing and services sectors are easily related to the sources of increasing returns that drive endogenous growth in modern growth theory. Baldwin and Forslid (2000), for example, introduced a Romer (1990) R\&D sector into the Krugman (1991) model by allowing for new manufactured goods and show that the integration of knowledge bases creates growth, even in the periphery, which compensates for losses of agglomeration there. What these models have in common is that they make regional development highly path-dependent. Initial conditions determine to a large extent where what type of economic activity will establish itself and how it will (fail to) grow.

A model that explicitly uses endogenous growth theory is a model of the product life cycle by Grossman and Helpman (1991b). As can be seen in Fig. 4, in this model Grossman and Helpman introduce an R\&D sector in both regions but have the advanced region develop new products, whereas the lagging region is merely imitating them. 


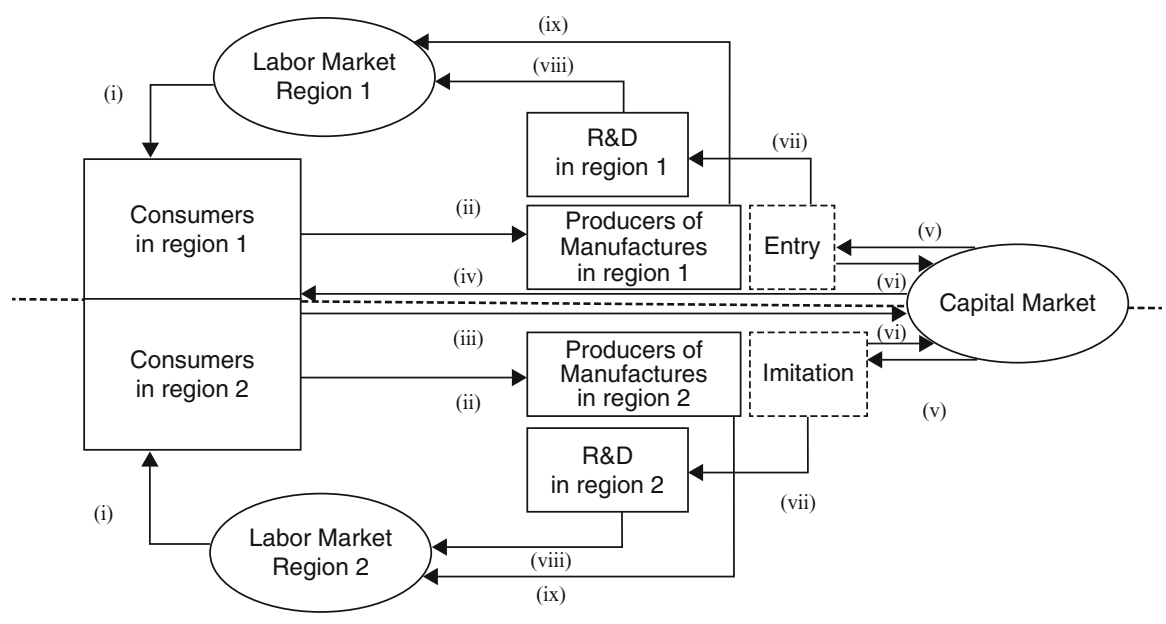

Fig 4 The Grossman-Helpman (1991b) model

In the model, total wage income (i) is spent on consumption (ii) of diversified final goods from regions 1 and 2. Consumers also save in a global capital market (iii) and receive interest (iv) on their assets. These savings are invested in new ventures (v) and repaid out of profits (vi). The required knowledge for a new or imitation venture is produced by and auctioned off by a local R\&D sector (vii), and both the R\&D and production sector compete and pay for labor (viii) and (ix) closing the model. There is free trade, but all final goods production is monopolistic, and consumers value variety and new product designs. This implies monopoly rents are available to incentivize knowledge creation. The backward region in the model, however, does not invent but rather copies the products developed in the advanced region, and of course this is easier when a lot of advanced products are available. Thus the model explicitly endogenizes regional and intertemporal knowledge spillovers and shows that growth in the periphery will benefit from knowledge creation in the core. In fact, in equilibrium the growth rates in both regions will equalize and the core has to "run to stand still" in terms of relative wages and income levels. Audretsch and Sanders (2011) extended this model to a threestage life cycle, showing inter alia that new labor rich countries and regions joining the global economy will leave the advanced region a more limited range of products and causes the fringe to catch up. In these models, however, information and knowledge will flow between the "advanced" and the "backward" region as water will run down a hill. Moreover, this model assumes labor immobility, suggesting the regions are geographically not very near.

\subsection{Knowledge Spillovers and the Role of Cities}

As endogenous growth theory has emphasized knowledge accumulation, either in the labor force or in the form of new products and processes, it is useful to distinguish "knowledge" from "information" as in Feldman and Audretsch (1999). 
Information is codified and can be transmitted over large distances at low costs. In fact, with modern communications technology, the costs of reproducing and transferring information are effectively zero. Knowledge, in contrast, is partially tacit and requires proximity and high quality two-way communication for effective knowledge transfer. If the positive externalities and increasing returns depend on others also benefiting from past knowledge creation, the intensity of personal interaction becomes a relevant factor in determining growth to the extent that knowledge is not information. For example, Florida (2005) discusses the impact of the creative class on regional development and finds that more open cultures perform better. This suggests that it is indeed the exchange of knowledge, particularly tacit knowledge, that drives prosperity and growth. The exchange of tacit knowledge requires open and intensive communications between people of very diverse backgrounds and perspectives. And as this intensity is higher and more diverse in a densely populated region, this puts urban, high-density regions center stage in the discussion.

Glaeser et al. (1992) in their seminal study of growth in cities tested three alternative theories of endogenous, knowledge spillover-driven economic growth in a sample of US cities. They tested the Marshall-Arrow-Romer approach that relies on within-industry knowledge spillovers and monopoly profits to motivate knowledge creation against the Porter approach that also emphasizes intra-industry knowledge spillovers but rather relies on competitive pressures to innovate and the Jacobs approach that instead relies on interindustry knowledge spillovers, where ideas cross-fertilize over industry boundaries. Perhaps surprisingly Glaeser et al. (1992) find that the data favor the latter theory, suggesting that specialization at the regional level is detrimental for growth. Feldman and Audretsch (1999), however, find that specialization does promote regional growth and development. De Groot et al. (2009) conclude from a meta-analysis of this literature that although most research supports Porter and Jacobs, the heterogeneity across regions, periods, and sectors seems large.

Whether good or bad for growth, it is an established fact that cities and urban regions typically are quite specialized and have become increasingly so. Smaller cities are more specialized than the large metropolitan areas, and as cities grow in size, they also tend to become more diversified. But this is largely so because larger cities attract the much more diversified business services. Ellison and Glaeser (1999) studied the reason for industries to concentrate in regional clusters and found that only $10-20 \%$ of the spatial pattern could be explained by natural advantages (access to port facilities and navigable rivers, presence of natural resources, etc.). The remaining $80-90 \%$ would have to be attributed to intra-industry spillovers. Cities attract these so-called "footloose" production activities, where location is not important, but agglomeration is.

Only considering the positive knowledge spillover externalities in the models, however, would lead us to the conclusion that agglomerations are typically too small. Given that there are positive externalities connected to the decision to locate in a given area by increasing its density, it would then make economic sense for cities to grow without bounds. This one-sided approach would thus imply that cities should become ever bigger and denser. But of course there are also negative externalities to consider. Henderson (2006) presents models of urban growth that 
rely heavily on endogenous growth models as described above. But he explicitly introduces the negative externalities connected to congestion and commuting. This introduces an inverted $\mathrm{u}$-shaped relationship between city size and total welfare and implies cities have an optimal size. This optimal size is shown to depend negatively on transportation and congestion costs and positively on benefits of agglomeration, total factor productivity, and human capital accumulation. Henderson (2006) shows that it depends on their institutional setting and quality whether actual cities will achieve this optimal size. One needs to either have local governments that can limit city size or free markets in which both negative and positive externalities are priced into land rents and local public goods provision, respectively. In the absence of such institutions, as arguably is the case in many developing countries, cities will grow beyond their optimal size. When the marginal migrant is indifferent between living in an overcrowded city and a sparsely populated rural village, the positive externalities of density in knowledge creation are fully offset.

\subsection{Concluding Remarks}

This section has reviewed the main models that turn endogenous growth models into models of regional endogenous growth. As endogenous growth models build on positive externalities connected to knowledge accumulation at the aggregate level, regional models of endogenous growth all have in common that they localize this process. New economic geography models will distinguish between knowledge accumulation in agriculture, manufacturing, and services to explain the coreperiphery patterns of economic activity, whereas urban economics models explain the existence and growth of urban agglomerations by focusing on the centripetal forces of localized knowledge spillover externalities. These models thus explicitly localize the knowledge spillovers that cause increasing returns in the aggregate growth models discussed above. One can localize the knowledge base on which new knowledge is created or link the creation of positive spillovers to density and proximity to explain spatial patterns of economic development. What these models do not endogenize, however, is the selection of what agents will take what actions to create and/or diffuse the knowledge into the regional economy. New economic geography and urban economics share with endogenous growth theory a relative neglect for the organizations and people that create or build on the new knowledge.

\section{The Organization of Knowledge Creation and Diffusion}

\subsection{Organizational Change as the Enabler of Economic Growth}

Aghion et al. (1999) pointed out the possible relevance of organizational change for economic growth. The organizational change literature stresses the fact that introducing new technology always requires a rethinking of the organization of the production process. In this literature, however, organizational change is not 
considered a root cause of economic growth and innovation. By optimizing the organization, productivity can be increased for a given set of technologies. But it is likely that this type of productivity increases run into severe diminishing returns in the absence of true technological innovation or knowledge accumulation.

Organizational change can never improve efficiency above $100 \%$ and push the technology frontier out by merely reorganizing the existing production techniques, knowledge, and outputs. The rate of knowledge accumulation thus ultimately limits productivity growth. But only when the appropriate organizational changes are made will newly acquired knowledge actually create growth.

For the current chapter, it is most relevant that their model relies primarily on the short- and medium-run adjustment process to new technology. Adopting new technology requires adaptive skills at the regional, local, and organizational level. The absence of such skills will slow down the rate of technological change even if knowledge creation is not the bottleneck in the innovation process, whereas an abundance will facilitate spillovers from outside. The Aghion et al. (1999) approach looks at this adjustment to new knowledge and technology as taking place predominantly within existing organizations and concludes that generally high-skilled workers will be in higher demand when technical and therefore organizational change is intense. The implicit assumption in this framework is that existing firms and organizations adopt and commercialize new knowledge and ideas. The entrepreneurship literature has focused instead on new firms and organizations as the vehicle for new knowledge commercialization.

\subsection{Entrepreneurship as the Conduit for Knowledge Spillovers}

Endogenous growth theory has largely considered knowledge accumulation as the key determinant of growth and consequently focused on explaining the accumulation of new knowledge. New economic geography and urban economics had already recognized the importance of local knowledge spillovers and were quick to link the tools in endogenous growth theory to local and regional economic activity. And organizational change theory addressed the skill requirements that follow from knowledge implementation in existing organizations. All these approaches, however, ignored the Schumpeterian distinction between invention, the creation of an idea, and innovation, the commercialization of that idea. The working assumption in most of the models discussed above is that inventions will automatically or trivially diffuse throughout the (local) economy causing innovation. There are telling examples, however, of firms that failed to commercialize the new knowledge developed in their own R\&D departments. Similarly, regions and organizations have sometimes failed to develop competitive advantages based on knowledge that was available. There can be many reasons, but it is obvious that idle knowledge will not cause economic growth. More generally, knowledge creation is a fundamental and definitely necessary, but not a sufficient, condition for generating economic growth.

A large body of literature on entrepreneurship shows that innovation and knowledge spillovers are far from trivial and automatic. Moreover, the process of 
commercialization is driven and restricted by very different incentives and constraints than knowledge creation. Arguably the entrepreneurial skill, attitudes, and infrastructure in a region will then co-determine how effectively that regional or urban economy implements and benefits from knowledge creation. There is quite some empirical evidence that supports the claim that at regional and local levels, it is (the lack of ambitious) entrepreneurship that explains the success and failure to turn knowledge creation into economic growth. The entrepreneurship literature long took the creation and existence of new business opportunities as exogenous and zoomed in on the entrepreneurial process of recognizing and exploiting opportunities instead. Its focus to date is largely empirical and shows strong regional differences in entrepreneurial activity that are closely correlated with economic growth and development. These differences can of course be related to the local presence or absence of new knowledge and ideas, but it has been shown that many other regional and individual variables play a role. Entrepreneurial attitudes and ambitions, local outside options for entrepreneurs and the presence of many small firms and entrepreneurs, a skilled labor force, and a high population density all seem to be of importance.

In Acs et al. (2009) and Acs and Sanders (2011), it was argued that entrepreneurship should be considered the "missing link," the key conduit (and bottleneck) for knowledge spillovers. It is not through the mere presence of or random interaction among many agents in a densely populated urban setting that knowledge diffuses and creates the positive externalities that endogenous growth theory assumes. The "knowledge spillover theory of entrepreneurship" (KSTE), as Acs et al. (2009) dubbed their approach, argues that it is entrepreneurs that deliberately transfer knowledge and transform invention into innovation in the pursuit of profit. In doing so this theory endogenizes the spillovers that were assumed to exist or arise costless and semi-endogenously in endogenous growth models discussed above. In that sense "an entrepreneurship theory of knowledge spillovers" might have been equally appropriate.

As such the KSTE opened up a range of new opportunities for thinking about endogenous models of regional growth. Consider the Acs and Sanders (2011) model represented in Fig. 5, where we took the Romer (1990) model and added the possibility for the final goods sector to hire labor to do R\&D (vii). To fund these investments, they need to borrow (viii) and repay (ix) their loans from additional profits. The R\&D in the final sector creates "upstream" knowledge spillovers that are free. The R\&D in a car manufacturing firm, for example, may create an occasional opportunity for an entrepreneur to become a new supplier of some part in the intermediate sector. The entrepreneurs can set up such a firm, but this requires labor (xiii) that has to be financed (xii), implying all existing intermediate firms also repay the start-up loan (xi).

The implications of the model are intuitive. In the absence of a pool of ambitious and skilled entrepreneurs, the knowledge spillovers are limited to within firm accumulation of knowledge. Entrepreneurs facilitate the knowledge spillovers that seem important in the Jacobs and Porter approaches, described above. One can also 


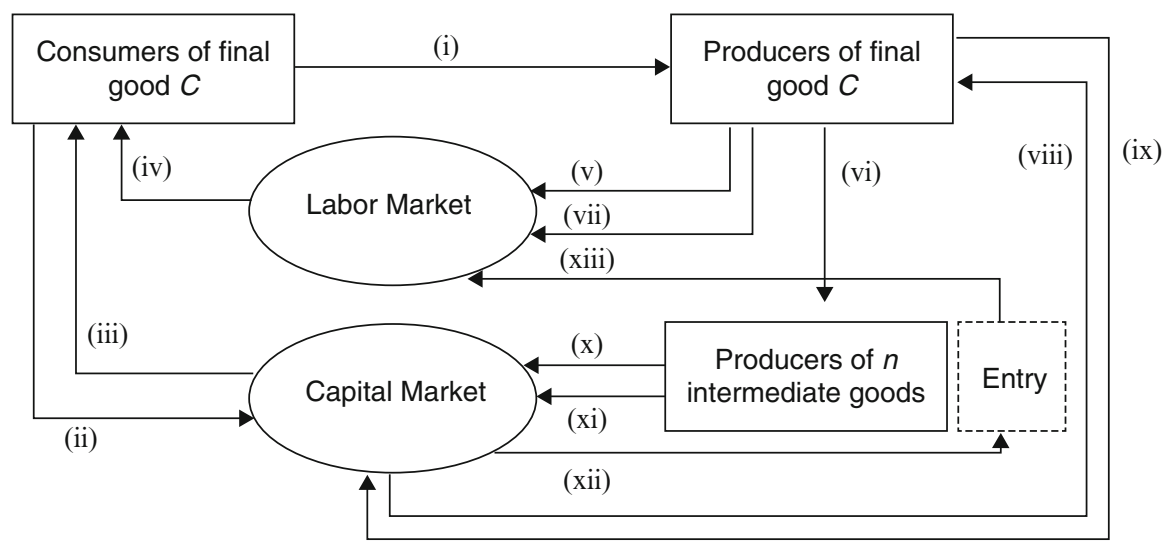

Fig 5 The Acs-Sanders (2011) model

put more emphasis on the occupational choice trade-offs, implicit in the model. By making entrepreneurship and employment perfect substitutes, wages equalize and the model implicitly assumes that workers are indifferent and homogenous. But of course one can extend this simple model in the spirit of Krugman (1991) and include many other individual and regional variables that will affect the basic trade off. Such a model would explain clustering of entrepreneurs in urban regions and detach the dynamics in the global knowledge base from local knowledge implementation. In dynamic settings with multiple regions, one will then be in a steady state when the labor allocation is more or less stable across regions and occupations and the marginal products of labor in knowledge generation, knowledge commercialization, and routine production equalize.

The many different externalities that exist in all three stages of the innovation life cycle all provide a link to location and urban economics, as some are closely related to proximity and density and others less so. The key conclusion from this theory is, however, that more knowledge creation will increase growth and development only through the innovative activities of entrepreneurs who turn information and ideas into a widely used and readily available knowledge base that facilitates further knowledge creation.

\subsection{Concluding Remarks}

When we turn our focus on the organizations and people that create and commercialize the new knowledge, new linkages through which endogenous growth is localized can be explored. On the one hand, existing organizations require skilled employees to absorb appropriate new technologies from outside and from within. In the absence of such absorptive capacity, existing firms in a region will not be able to internalize and build upon the knowledge created. The spillover theory of 
entrepreneurship on the other hand stresses the role of entrepreneurs in transferring knowledge from the drawing board to the market place, providing an alternative missing link between invention and innovation. Both approaches shift the focus from local knowledge creation to local knowledge commercialization, where different mechanisms are at work.

\section{$5 \quad$ Fundamental Causes of Growth and Development}

\subsection{Institutions and Economic Growth}

Institutions are broadly defined as "the manmade rules of the game." For a long time, (growth) economists have treated institutional differences, much like, for example, differences in geography and preferences, simply as given. In searching to explain the cross-country differences in growth performance over longer periods of time, however, several authors have now argued that institutions play an important role in determining growth. The empirical evidence that causality runs from institutional quality to economic performance is mounting, since Acemoglu et al. (2001) showed a clear link between sixteenth century settler mortality rates and modern institutional quality and used this as an instrument in their empirical analysis. Without going into technical detail too much, this chapter clearly establishes the importance of institutional quality for development and growth. This takes the endogenization of economic growth and innovation one step further. The institutional approach is more fundamental than the modeling approaches above and puts a strong emphasis on growth as a historical process.

Still, the institutional approach to date largely abstracts from geography and location. Acemoglu (2009) dismisses geography (and the alternative hypotheses that it is all about luck or culture) as a fundamental cause of economic growth by arguing that climatic and geographic circumstances fail to explain why some countries did and some did not industrialize. This exclusive focus on "first nature" geography obscures the importance of second nature geography that new economic geographers and urban economists tend to stress and that has been the core of their work. It is, however, hard to see where this neglect will take institutional growth theory. Recent contributions focus on explaining the endogenous emergence and persistence of growth enhancing or inhibiting institutions. The natural inclination in this data driven literature is to think first about political institutions at the national level supporting or inhibiting knowledge creation. Models in this field, for example, explain the transition from autocracy to democracy as a result of power struggles and apply game theory and political economy techniques to explain institutional change. Many of the formal institutions (property rights, rule of law, democracy, etc.), however, do not vary across regions and locations in the same country, whereas informal institutions (culture, attitudes toward the new and experimentation, etc.) differ quite a bit between core and periphery in general and across different regions and cities as well. 
As Florida (2005) has shown, more open cultural attitudes correlate highly with standards of living and economic performance. And Baumol (1990) already argued that it is institutions that will also mobilize entrepreneurial talent into or out of the productive activity of taking knowledge from the drawing board to the market place. Both would probably agree that it is local, informal institutions in cities and regions that matter as much or more than the formal, legal, and political institutions at the national level for enabling and promoting the knowledge spillovers that endogenous growth theory models at the aggregate level.

An interesting, but to date largely unexplored, line of research would therefore focus more on the importance of local and regional institutional differences and zoom in on their beneficial or detrimental effects on knowledge creation and diffusion at the regional level. Attempts in this direction have been made by scholars taking a much more empirical and case-based "regional systems of innovation" approach that is very popular with policy makers. Anselin et al. (1997) already showed that knowledge spillovers are highly localized, whereas Audretsch and Lehman (2005) establish a link between local knowledge creation and commercialization activity. These facts certainly call for stronger theoretical underpinning. The institutional approach to economic growth, however, is currently asking very different questions. Inspired by aggregate endogenous growth theory, it focuses almost exclusively on the process of knowledge creation, and the supporting empirical work will continue to draw predominantly on panel databases that have countries as their geographic unit.

\subsection{Concluding Remarks}

Recent contributions to the empirics of economic growth have established that institutions play a key role in driving growth and development at the aggregate level. The current challenge in this literature is to link these national institutions to the process of knowledge creation. We feel that this research line neglects endogenous knowledge spillovers at the regional level. Likewise, recent evidence in economic geography suggests that local growth and development patterns are driven largely by the interaction between knowledge creation and commercialization. But this literature still largely ignores local institutions as, for example, very different cultural attitudes toward entrepreneurship and innovation in cities and their periphery. The institutional approach to aggregate economic growth will remain free of geography as long as it ignores the importance of proximity for the assumed knowledge spillovers, whereas economic geography and urban economics will remain free of institutions as long as their importance for attracting and mobilizing creative and entrepreneurial talents is not recognized. Of course, exploring the implications of institutional differences among regions and cities, on the one hand, and second nature geography in knowledge creation and spillovers opens up a broad research agenda for both theory and empirical research in the field of endogenous regional growth. 


\title{
6 Conclusions
}

In this chapter we have first reviewed basic endogenous growth theory to show that economic growth is ultimately dependent on new knowledge creation. This new knowledge creation, however, builds on the existing knowledge base, causing increasing returns to scale at the aggregate level. This same mechanism has been shown to operate at the local and regional level in models of new economic geography and urban economics that aim to explain spatial patterns of economic activity and growth. More specifically we showed that the mechanism of endogenous economic growth can account for stable city growth and core-periphery patterns of economic activity. When we dig into the process of knowledge creation a bit more, we have to distinguish between knowledge creation and commercialization. The former is of course a necessary condition for growth, but the latter may well be the more important bottleneck for growth at the regional level. In addition, commercialization is a way to make new knowledge available to those who would otherwise not be able to build upon it. Arguably the commercialization, rather than the inception of a new idea, has the biggest impact on economic performance and enables future knowledge spillovers to take place. Moreover a focus on the people and organizations that are responsible for commercialization allows for another fruitful avenue for localizing endogenous growth. Finally, we have discussed how the most recent developments in economic growth theory, toward a more institutional approach to economic growth, once more seem to neglect the importance of geography. Institutions have been shown to affect local, organizational absorptive capacity and both the attitudes and actions of entrepreneurs. Linking such insights with the modeling tools as they are developed in the mainstream of macroeconomic growth theory will certainly constitute a fruitful and important agenda for future research.

\section{$7 \quad$ Cross-References}

\author{
Agglomeration and Jobs \\ - Changes in Economic Geography Theory and the Dynamics of Technological \\ Change \\ Cities, Knowledge, and Innovation \\ - Clusters, Local Districts, and Innovative Milieux \\ - Demand-Driven Theories and Models of Regional Growth \\ - Evolutionary Economic Geography and Relational Geography \\ - Knowledge Flows, Knowledge Externalities, and Regional Economic \\ Development \\ Knowledge Spillover Theory \\ - Neoclassical Regional Growth Models \\ - Regional Growth and Convergence Empirics
}


Systems of Innovation and the Learning Region

- The Geography of Innovation

- The Rise of Skills: Human Capital, the Creative Class, and Regional Development

\section{References}

Acemoglu D (2009) Introduction to modern economic growth. Princeton University Press, New York

Acemoglu D, Johnson S, Robinson J (2001) The colonial origins of comparative development: an empirical investigation. Am Econ Rev 91(5):1369-1401

Acs Z, Sanders M (2011) Patents, knowledge spillovers and entrepreneurship. Small Bus Econ 34 (1). https://doi.org/10.1007/s11187-011-9322-y

Acs Z, Audretsch D, Braunerhjelm P, Carlsson B (2009) The knowledge spillover theory of entrepreneurship. Small Bus Econ 32(1):15-30

Aghion P, Howitt P (1991) A model of growth through creative destruction. Econometrica 60 (2):323-351

Aghion P, Caroli E, Garcia-Penalosa C (1999) Inequality and economic growth: the perspective of new growth theories. J Econ Lit 37(4):1615-1660

Anselin L, Varga A, Acs Z (1997) Local geographic spillovers between university research and high technology innovations. J Urban Econ 42(3):422-448

Audretsch D, Lehmann E (2005) Does the knowledge spillover theory of entrepreneurship hold for regions? Res Policy 34(8):1191-1202

Audretsch D, Sanders M (2011) Technological innovation, entrepreneurship and development. In: Szirmai E, Naude W, Goedhuys M (eds) Entrepreneurship, innovation and economic development. Oxford University Press, Oxford, pp 35-64

Baldwin R, Forslid R (2000) The core-periphery model and endogenous growth: stabilizing and destabilizing integration. Economica 67(267):307-324

Barro R (1996) Democracy and growth. J Econ Growth 1(1):1-27

Barro R, Sala-I-Martin X (2004) Economic growth, 2nd edn. The MIT Press, Cambridge

Baumol W (1990) Entrepreneurship: productive, unproductive and destructive. J Polit Econ 98 (5):893-921

Becker G (1964) Human capital. Columbia University Press, New York

de Groot H, Poot J, Smit M (2009) Agglomeration externalities, innovation and regional growth: theoretical perspectives and meta-analysis. In: Capello R, Nijkamp P (eds) Handbook of regional growth and development theories. Edward Elgar, Cheltenham, pp 256-281

Desai S, Acs ZJ, Weitzel U (2013) A model of destructive entrepreneurship: insight for conflict and postconflict recovery. J Confl Resolut 57(1):20-40

Ellison G, Glaeser E (1999) The geographic concentration of industry: does natural advantage explain agglomeration? Am Econ Assoc Papers Proc 89(2):311-316

Feldman M, Audretsch D (1999) Innovation in cities: science based diversity, specialization and localized competition. Eur Econ Rev 43(2):409-429

Florida R (2005) Cities and the creative class. Routledge, New York

Giesen C, Südekum J (2011) Zipf's law for cities in the regions and the country. J Econ Geogr 11 (4):667-686

Glaeser E, Kallal H, Scheinkman J, Schleifer A (1992) Growth in cities. J Polit Econ 100 (6): 1126-1152

Grossman G, Helpman E (1991a) Innovation and growth in the global economy. The MIT Press, Cambridge

Grossman G, Helpman E (1991b) Endogenous product cycles. Econ J 101(409):1214-1229

Henderson V (2006) In: Aghion P, Durlauf S (eds) Urbanization and growth. Handbook of economic growth. Elsevier-NorthHolland, New York, pp 1543-1591 
Jones CI (1995) R \& D-based models of economic growth. J Polit Econ 103(4):759-784

Krugman P (1991) Increasing returns and economic geography. J Polit Econ 99(3):483-499

Lucas R (1988) On the mechanics of economic development. J Monet Econ 22(1):3-42

Romer P (1990) Endogenous technological change. J Polit Econ 98(5):S71-S102

Sanders M, Weitzel U (2013) Misallocation of entrepreneurial talent in postconflict environments. J Confl Resolut 57(1):41-64

Solow R (1957) Technical change and the aggregate production function. Rev Econ Stat 39 (3):312-330

Temple J (1999) The new growth evidence. J Econ Lit 37(1):112-156 